\title{
A study of $\mathrm{TiO}_{2}$ binder-free paste prepared for low temperature dye sensitized solar cells - ERRATUM
}

Jeremy H. Yune, Inna Karatchevtseva, Gerry Triani, Klaudia Wagner, and David Officer

doi: 10.1557/jmr.2012.354, Published by Cambridge University Press, 12 November 2012.

On the article opening page, the third author's name was incorrectly published as "Gerri Triani."

The correct spelling is Gerry Triani.

The publisher regrets the error.

\section{REFERENCE}

1. Jeremy H. Yune, Inna Karatchevtseva, Gerry Triani, Klaudia Wagner, and David Officer: A study of $\mathrm{TiO}_{2}$ binder-free paste prepared for low temperature dye sensitized solar cells. J. Mater. Res. 28 (2013). 